\title{
Eugenia e imigração: diálogos com a Constituinte 1933-1934 ${ }^{1}$
}

\author{
Eugenics and immigration: dialogues with the 1933-341933-1934 Constituent Assembly
}

\author{
Wallace Carvalho de ANDRADE* \\ Prefeitura Municipal de Paracambi/PPRER \\ Maria Cristina GIORGI** \\ Centro Federal de Educação Tecnológica Celso Suckow da Fonseca (CEFET/RJ)
}

\begin{abstract}
RESUMO: Neste artigo, buscamos, por meio da articulação entre questões de linguagem (BAKHTIN, 2003, 2011; DUCROT, 1987; MAINGUENEAU, 1997, 2008, 2013) e étnicoraciais, especificamente a eugenia (SKIDMORE, 2012) discutir as imagens de imigração e o modo como o racismo se fez presente em uma constituinte, órgão colegiado que, com plenos poderes, visa redigir ou reformar a constituição, e, consequentemente, a ordem políticoinstitucional. Para tal, após breve discussão acerca das condições históricas que propiciaram a emergência de discursos racista na Assembleia Nacional Constituinte 1933-34, apresentamos análises de seus anais, que mostram o modo como as imagens de imigrantes se materializam nos referidos documentos. Nossos resultados apontam para um claro alinhamento com diretrizes pautadas em modelos eugenistas propostos por estados estrangeiros, que consideram a imigração de certos grupos prejudicial para o Brasil, sobretudo para a prosperidade econômica da nação.
\end{abstract}

PALAVRAS-CHAVE: Racismo e eugenia. Imigração na Assembleia Constituinte 1933-34. Dialogismo. Análise do discurso.

ABSTRACT: In this paper, by articulating language theorizations (BAKHTIN, 2003, 2011; DUCROT, 1987; MAINGUENEAU, 1997, 2008, 2013) and ethnic-racial issues, specifically eugenics (SKIDMORE, 2012) we wish to discuss the images of immigration and how racism expressed itself in a National Constituent Assembly - a collegiate organ with unrestrained powers whose purpose is to rewrite or reformulate the Constitution, and, by extension, the political-institutional order. As a starting point, we briefly revisit the historical conditions which allowed for the emergence of racist discourses in the 1933-1934 Constituent Assembly; we then move on to the analysis of its annals, with a view to showing how the images of immigrants were depicted. Our results underscore an alignment with eugenics-based orientations put forth by foreign States, which believed the immigration of certain groups to be harmful to Brazil, especially for the economic prosperity of the nation.

KEYWORDS: Racism and eugenics. Immigration in the 1933-1934 Constituent Assembly. Dialogism. Discourse analysis.

\footnotetext{
1 Este artigo é desdobramento da pesquisa de mestrado desenvolvida no curso de Pós-Graduação em Relações Étnico-Raciais (PPRER), no CEFET/RJ, intitulada Eugenia, raça e imigração: diálogos com a Constituinte 1933-1934, defendida em 2017, pelo docente Wallace Carvalho de Andrade, orientada pela Profa. Dra. Maria Cristina Giorgi e coorientada pelo Prof. Dr. Samuel Silva Rodrigues de Oliveira.

* Mestre em Relações Étnico-Raciais pelo PPRER, CEFET/RJ e especialista em História da África e do Negro no Brasil no Centro de Estudos Afro-Asiáticos da Universidade Cândido Mendes. Atua como professor de história na Secretaria de Educação e Desportos do município de Paracambi.

*** Doutora em Estudos da linguagem pela UFF, professora CEFET/RJ, onde atua no Ensino Médio e Ensino Técnico e nos programas stricto sensu em Relações Étnico-Raciais e Filosofia e Ensino, além de coordenar o curso lato sensu Relações Étnico-Raciais e Educação.
} 


\section{Introdução}

$\mathrm{Na}$ sociedade brasileira, a passagem do século XIX para o XX apresenta profundas transformações sociais e políticas - como a abolição do sistema escravista, a partir da qual a maioria da população brasileira passa a ser composta por exescravizados -, causando enorme preocupação às classes dirigentes da época no novo sistema republicano, alinhadas ao pensamento europeu e às teorias racialistas hegemônicas, sustentadas pelo determinismo biológico e por modelos evolucionistas baseados nas teorias de Darwin e Spencer. A população branca, vista como superior, passa a ser ameaçada pelo aumento da população negra. De acordo com as teorias racialistas - que legitimaram a colonização da Ásia e África no século XIX, resultado da política imperialista adotada pelas nações europeias nos continentes africano e asiático -, o negro é um ser quase animalesco, com características físicas e psíquicas inferiores, fadado ao fracasso, em oposição a um branco, intelectualmente elevado e destinado às melhores posições na sociedade.

Como consequência, países colonizados como o Brasil não alcançam o status de civilização das nações europeias, aquelas que produziram os intelectuais que respaldaram cientificamente tais teorias, hegemônicas na segunda metade do século XIX, cuja validação científica era outorgada por intelectuais da época, como Gobineau (1816-1882), Lapouge (1854-1936), Agassiz (1807-1873), Lombroso (1835-1909), Paul Broca (1824-1880), dentre outros. Para os seguidores dessas correntes, o atraso de nosso país, em oposição à modernização vigente, dava-se em função da intensa miscigenação ocorrida em solo brasileiro.

Graham retrata esse período como medo da desordem, pois "o fato de que o Brasil dependia do trabalho escravo pode explicar por que a desordem social era tão ameaçadora às classes dominantes, durante o segundo quartel do século XIX" (GRAHAM, 2001, p. 39).

Exemplifica essa visão o texto do zoólogo suíço Louis Agassiz (1807-1873), que, após viagem ao Brasil em 1865, teceu severas críticas ao nosso "caldeirão de raças", reproduzidas pelo brasilianista Thomas Skidmore: 


\begin{abstract}
Que qualquer um que duvida dos males dessa mistura de raças, e se inclina, por mal-entendida filantropia, a botar abaixo todas as barreiras que as separam, venham ao Brasil. Não poderá negar a deterioração decorrente do amálgama de raças, mais geral aqui do que em qualquer outro país do mundo, e que vai apagando rapidamente as melhores qualidades do branco, do negro e do índio, deixando um tipo indefinido, híbrido, deficiente em energia física e mental (AGASSIZ, 1868, apud SKIDMORE, 2012, p. 72).
\end{abstract}

Desse modo, durante a Primeira República, a única solução brasileira encontrada para resolver o "problema do negro", a essa altura o principal responsável pelo fato de o estado brasileiro não atingir o status de civilização moderna, passa a ser o branqueamento. Dentro desse contexto, diversos intelectuais nacionais alinham-se a discursos científicos, com o escopo de salvar a nação, considerada atrasada pela ótica das teorias racialistas europeias, e adotam a eugenia como saber autorizado e legitimado, reproduzindo-a nos textos da constituinte, no intuito de branquear a população brasileira, de modo a equivaler-se aos países europeus, considerados de elevado grau de civilização. Costa chega a asseverar que "Nina Rodrigues investiga grupos populacionais negros na região de Salvador, concluindo que estes apresentam, ao lado de uma vigorosa produção cultural, uma iniludível inferioridade intelectual que impediria sua integração na nação em igualdade de condições com brancos" (COSTA, 2001, p. 145).

Neste artigo, portanto, pretendemos, por meio de análises que apontam para diálogo entre questões de linguagem e étnico-raciais, colocar em discussão a materialização desses discursos na Assembleia Nacional Constituinte 1933-34, órgão que tem plenos poderes para redigir ou modificar a anterior constituição.

Sendo assim, primeiramente apresentamos a concepção de linguagem que norteia nossa argumentação; em seguida algumas noções sobre racismo e pensamento eugênico, para, finalmente, introduzirmos a Assembleia Nacional Constituinte, iniciando pela contextualização histórica e terminando pelas análises, antes das considerações finais.

\title{
1. Questões de linguagem
}


Evidentemente, afastamo-nos de concepção, ainda difundida, que entende a linguagem como uma mensagem com um conteúdo a priori, a ser decodificado, e despreza as relações entre os interlocutores na produção dos sentidos. Aproximamo-nos, portanto, da concepção dialógica e polifônica da teoria de Bakhtin (2011), conforme a qual toda compreensão é ativamente responsiva, porque o próprio falante "está determinado precisamente a essa compreensão ativamente responsiva: ele não espera, por assim dizer, que apenas duble o seu pensamento em voz alheia, mas uma resposta, uma concordância, uma participação, uma objeção, uma execução, etc.” (BAKHTIN, 2011, p. 272).

\begin{abstract}
A língua, como sistema de formas que remetem a uma norma, não passa de uma abstração, que só pode ser demonstrada no plano teórico e prático do ponto de vista do deciframento de uma língua morta ou de seu ensino. Esse sistema não pode servir de base para a compreensão e explicação dos fatos lingüísticos enquanto fatos vivos e em evolução (BAKHTIN, 2003, p. 108).
\end{abstract}

Levando em conta essa visão, compreendemos que o interlocutor passa a construir sentidos a partir dos saberes que mobiliza, em lugar de ser um mero receptor, mesmo porque, não necessariamente, o sentido original construído pelo enunciador coincide com o construído pelo coenunciador, uma vez que os dois têm uma história, um saber, que lhes permitirá ter acesso ou não a essa construção. Não é possível, portanto, que haja sentidos estáveis e pré-estabelecidos em um enunciado, que é somente uma unidade real da comunicação, vinculado às relações entre os interlocutores e em cujos cruzamentos se preserva a memória social.

Dessa forma, considerando a concepção dialógica bakhtiniana, recorremos a autores que tratam da presença de diferentes vozes numa única enunciação, distinguindo locutores de enunciadores (MAINGUENEAU, 1997, DUCROT, 1987). Ducrot entende o locutor como responsável pela enunciação, designado pelos pronomes e marcas textuais, como as de segunda pessoa. Já o enunciador, que não se confunde com o locutor, é um sujeito discursivo e não empírico, que se constrói a partir dos enunciados.

Por sua vez, afirma Maingueneau, mesmo as vozes dos enunciadores estando na enunciação, não se pode atribuir a elas palavras precisas; eles não falam, mas têm seus 
pontos de vista materializados na enunciação (MAINGUENEAU, 1997). Sendo assim, o locutor tem a possibilidade de colocar em jogo, em seu enunciado, vozes que não são as suas.

Aproximando essa perspectiva do nosso córpus de análise, entendemos que os textos resultantes das reuniões de trabalho dos deputados constituintes na Assembleia Nacional 1933-34 (doravante ANC) permitem-nos melhor compreender as diversas concepções a respeito da formação e modernização do Estado brasileiro, em disputa naquele momento. Afinal, todo texto é, em certa medida, uma montagem consciente, ou inconsciente, da história, da época, da sociedade que o produziram. E nos interessa identificar de que modo tal embate dialoga com teorias racialistas europeias - que condenam a sociedade brasileira ao fracasso, em função da mistura racial - e também com aqueles que não aderem às referidas teorias.

Antes de falarmos especificamente das questões relativas ao racismo é essencial ainda, retomando os diálogos com Rocha (2006), entender que, mesmo tendo um poder de representar o mundo, a linguagem produz uma certa versão desse mundo, nele intervindo (ROCHA, 2006). Assim, no que concerne às questões étnico-raciais, mais relevante se faz essa intervenção, quando

\footnotetext{
se coloca em pauta que os enunciados só são produzidos por um sujeito no momento em que esse atua em situações sociais, dado que é nessas situações que se assume a condição de sujeito. Fazemos parte de uma sociedade na qual brancos e negros ainda ocupam lugares discursivos distintos, são sujeitos que têm relações diversas com os lugares dos quais enunciam, o que se materializa diretamente em seus enunciados. Numa sociedade em que sabidamente o racismo determina lugares de subordinação às pessoas negras, os sentidos não podem ser dissociados das relações com os lugares nos quais esses sujeitos estão inseridos, nem da produção de efeitos de sentido, que se materializa por meio de sujeitos sociais historicamente situados (GIORGI, BIAR, BORGES, 2015, p. 206).
}

Tendo em vista essa discussão, as reuniões de trabalho da Constituinte 1933-34 não eram apenas uma representação de Brasil doente e atrasado, "um imenso hospital" como proferiu Miguel Pereira em seu discurso na Faculdade de Medicina do Rio de Janeiro (FMRJ) no dia 10 de outubro de 1916, mas também mais uma intervenção por meio da qual se reproduzem e reforçam esses discursos, sobretudo aqueles em que a 
"salvação da nação" estaria na modernização do Estado brasileiro através das instituições políticas, da higienização, saneamento e da imigração europeia; onde todas essas esferas de ações estavam amparadas em discurso eugenista.

Nesse sentido, trabalhar, por exemplo, com os implícitos e com o não-dito pode nos auxiliar a recuperar as imagens de imigração que se constroem ao longo das enunciações. Conforme Ducrot (1987), o fato de a língua ser um jogo, no qual as relações interpessoais de seus jogadores estão atravessadas por tabus, implica uma distinção dos tipos de informação transmitidos, já que ao mesmo tempo em que coisas podem ser ditas outras não podem. E também há aquilo que só podemos dizer com a certeza de não assumirmos nenhuma responsabilidade por tê-lo dito. Se pensamos em nos embates que envolvem uma Constituinte, dizer sem dizer ou ser responsável por ter dito, em diversos momentos, pode ser uma estratégia discursiva bastante eficiente, e, dessa forma, jogar com enunciados de modo explícito e/ou implícito é essencial para os agentes do jogo linguístico: "a referência implícita a uma situação pressuposta é uma das características mais fundamentais da linguagem, e não uma habilidade subsidiária" (DUCROT, 1987, p. 19).

Ainda de acordo com Ducrot (1987, p. 202), a distinção entre enunciador e locutor é indispensável para ser introduzida na significação das frases negativas: "toda vez que se diz algo, imagina-se alguém que pensaria o contrário e ao qual se se opõe". Ao dizer "Pedro é gentil", supõe-se geralmente que há alguma razão para se acreditar nisso. No entanto, se dizemos "Pedro não é gentil", retomamos imediatamente a existência do positivo "alguém diz que Pedro é gentil, mas eu não concordo". Para Ducrot (1987, p. 203), esses enunciadores têm estatutos diferentes, visto que no enunciado negativo, "o lugar deste enunciador já está marcado na frase”, pois “a atitude positiva à qual o locutor se opõe é interna ao discurso no qual é contestada. Esta negação "polêmica" tem sempre um efeito rebaixador e mantém os pressupostos" (DUCROT, 1987, p. 204).

A seguir discorremos sobre racismo e eugenia.

\section{Racismo e eugenia}


O termo raça, ao longo do tempo e do espaço na história das sociedades humanas, esteve vinculado a sentidos diversos, motivo pelo qual devemos entendê-lo como uma categoria espaço-temporal, cujo surgimento data nos finais do século XVIII, para designar descendência comum de um conjunto de pessoas (BANTON, 1977, p. 39), sendo primeiramente desenvolvido sob a perspectiva da linhagem e utilizado para explicar as novas relações sociais que se configuravam na Europa Ocidental. A partir do século XIX, passou a ser utilizado como meio de classificar as pessoas a partir das diferenças fenotípicas e biológicas sob o aporte científico da antropologia e das ciências naturais.

Por sua vez, racismo é uma crença na existência de raças naturalmente hierarquizadas pela relação intrínseca entre o físico e o moral, o físico e o intelecto, e o físico e moral. Dessa forma,

o racista cria a raça no sentido sociológico, ou seja, a raça no imaginário do racista não é exclusivamente um grupo definido pelos traços físicos. A raça, em sua concepção, é um grupo social com traços culturais, linguísticos, religiosos, etc. que ele considera inferiores ao grupo o qual pertence (MUNANGA, 2004, p. 24).

No caso brasileiro, concedem materialidade ao racismo discursos que entendem que a ideologia do branco o constitui enquanto detentor de boa índole, cultura superior, apreço ao trabalho e valores éticos e civilizatórios, ao passo que ao negro cabem má índole, cultura inferior, e desprezo ao trabalho. Ao branco cabe governar e ocupar os melhores cargos; aos negros transitar nos espaços mais subalternos e inferiores da sociedade.

Justifica-se, desse modo, um racismo que se desenvolve por meio da ideologia do branqueamento que, à época, se constituiu por meio de práticas sociais, representações e discursos, defendidos por parte da intelectualidade brasileira no intuito de resolver o problema do negro na recém-proclamada república, uma vez que o negro, ao almejar o branqueamento como um ideal, identificava no branco o modelo a ser seguido.

É dentro desse contexto que entra em cena o movimento eugenista brasileiro, 
influenciado pelas citadas teorias racialistas, no início do século XX, que se intensifica a partir dos anos 1920-30 com a criação de diversas associações, órgãos, ligas, congressos, a fim de dar legitimidade às suas ideias. O campo intelectual, contudo, não era homogêneo. Existiam aqueles que consideravam ser o caldeirão das raças o responsável pelo atraso nacional, e os que divergiam de tais concepções, ao julgarem doenças e a falta de saneamento como verdadeiros problemas a serem combatidos via ações do Estado. Divergências à parte, os intelectuais eugenistas possuíam como interesses comuns a acumulação de capital social e lograr espaço no campo de poder.

Os movimentos eugênicos que eclodiram na América Latina eram inspirados no velho continente, em países como Inglaterra, França, Itália e Estados Unidos. Compreendemos que integrar os movimentos latino-americanos à história da eugenia é ampliar e enriquecer nossas reflexões.

O Brasil, último país das Américas a abolir a escravatura, foi a primeira nação da América Latina a ter um movimento eugênico organizado, em função de quatro aspectos. O primeiro foi a entrada do Brasil - visto como degenerado e inviável à civilização -, na Primeira Guerra ao lado dos aliados, em 1917, possibilitando a projeção do país no cenário internacional.

O segundo aspecto foi de a eugenia ter surgido como resposta às questões nacionais, das quais se destacam a miséria, as taxas elevadas de desemprego e a falta de saúde da população, em grande parte negra. Como é sabido, o Brasil foi um dos países que mais importou escravizados de origem africana e um dos últimos a realizar a abolição do sistema escravista, após a qual o negro fora lançado à própria sorte, sem qualquer condição de competir, na nova ordem social que se formava, com o imigrante branco.

O estágio em que a ciência brasileira se encontrava constituiu o terceiro aspecto para a compreensão do desenvolvimento da eugenia no Brasil. Diferente, por exemplo, da Grã-Bretanha, influenciada pela genética mendeliana, em nosso país predominou a tendência que ficaria conhecida como neolamarckismo reformista, desenvolvida na França, país que influenciaria fortemente nossos intelectuais do início do século XX e que possuía como linha de combate ações direcionadas ao meio ambiente. Dessa 
maneira, além do controle pelos exames pré-nupciais, matrimônio e esterilização, a "transformação do meio ambiente era indispensável para a proliferação de bons frutos", dado que "sanear, também é eugenizar", afirmação que fez os eugenistas britânicos entenderem que a eugenia brasileira teve abordagem mais sociológica do que biológica (STEPAN, 2005).

O último aspecto que facilitou o desenvolvimento da eugenia no país foi condicionado pela situação racial do país em função da alta mestiçagem, já que também se pode compreender eugenizar como branquear. Desse modo, as políticas eugenistas adotadas pelo Estado, seriam os agentes do branqueamento da sociedade, com vistas ao progresso, modernização e civilização, palavras-chave na época. Assim, a eugenia - por definição, a ciência do "aprimoramento racial" - era um atrativo óbvio para uma elite convencida do poder da ciência para criar "ordem e progresso" (lema da República) e perturbada pela composição racial do país (STEPAN, 2005, p. 339).

Comungando com a mesma lógica, também a imigração deveria servir ao modelo eugenista e, para tal, era preciso selecionar bem a entrada dos imigrantes, que seriam necessários para a regeneração e modernização do país, cabendo aos intelectuais influenciados pelos ideais eugênicos definir os critérios reguladores da entrada de estrangeiros, que viriam ocupar as terras devolutas, especialmente na região sul, formada atualmente pelos estados do Paraná. Santa Catarina e Rio Grande do Sul.

A partir de 1870, ano que marca a crise do Império, a entrada de estrangeiros concretiza o projeto de modernização do Brasil, cuja principal marca é a substituição da mão de obra escravizada pela branca europeia, considerada superior pelas teorias racialistas hegemônicas legitimadas pela antropologia. Em suma, inicia-se um processo de branqueamento da população brasileira, levado avante pelas classes dirigentes nos finais do XIX e intensificado na política republicana durante os anos 1920, que se materializa nos discursos da Assembleia Nacional Constituinte, nossa próxima discussão.

\section{Do contexto de produção à análise dos anais da Assembleia Nacional Constituinte}


As reuniões em torno da Assembleia Nacional Constituinte (ANC), realizadas entre os anos de 1933 e 1934, permitem que compreendamos melhor as lutas ocorridas dentro do campo político e a atuação de intelectuais médicos, antropólogos e juristas nos debates em torno da entrada de estrangeiros no país. Tendo em vista a proposta de arqueologia foucaultiana (2009), por meio da qual entendemos que o que foi dito instaura uma realidade discursiva e que sujeitos e objetos não existem a priori, são construídos discursivamente sobre o que se fala sobre eles, cabe uma breve explicação do contexto histórico em questão. No processo histórico da década de 1930, que culminou com a Revolução de 1930, Constitucionalista de 1932 e a formação de uma nova Constituição, é de suma importância o ano de 1922, pois:

\footnotetext{
Nele eclodem quatro acontecimentos simbólicos que contêm, em embrião, a mutação da sociedade brasileira entre as duas guerras mundiais. A Semana da Arte Moderna, em fevereiro, desencadeia a revolução estética; uma nova etapa da organização política da classe operária se delineia, em março, com a fundação do Partido Comunista Brasileiro; a criação do Centro D. Vital, ligado à revista $\mathrm{A}$ Ordem, de orientação católica, prenuncia a renovação espiritual; e, finalmente, a primeira etapa da revolução política tenentista irrompe, em julho, com a rebelião na Fortaleza de Copacabana (TRINDADE, 1974 , p. 15)
}

Em 1929, a Aliança Liberal, formada por ex-presidentes e participantes do movimento tenentista, lança a candidatura de Getúlio Vargas, derrotado nas eleições, em oposição à de Júlio Prestes, apoiado pela elite paulista. Após o fracasso nas urnas, o vice de Getúlio foi assassinado, fato que gerou revoltas populares em todo o país.

Eclode a revolução em outubro, e no dia 3 de novembro Vargas assume a chefia do Governo provisório da nação, instaurado com a ajuda de militares. Suas primeiras medidas são o fechamento do Congresso Nacional e das assembleias estaduais e municipais, a destituição dos governadores de estados e a revogação da Constituição de 1891. O evento abre espaço para os debates de projetos políticos, de modo a permitir que as classes de intelectuais pudessem apresentar propostas capazes de se traduzirem em ação governamental, em confronto com um Estado Nacional brasileiro fraco, responsabilizado pelos males da nação.

Em julho de 1932, eclode uma revolução em São Paulo sob o comando de Isidoro Dias, um dos tenentes revoltosos durante a década de 1920 e revolucionário de 
1930, visto que os paulistas, insatisfeitos com a política centralizadora de Vargas e com a morosidade das medidas que restaurariam o Estado de Direito, exigiam o fim imediato do regime ditatorial e maior autonomia para São Paulo. Após o referido levante, foram convocadas eleições para o Legislativo, das quais saíram os deputados responsáveis pela elaboração de uma nova Constituição.

O órgão colegiado denominado ANC tem como função a redação ou a reforma de uma anterior constituição, e, consequentemente, na ordem político-institucional de um Estado, sendo, para isso, dotada de plenos poderes ou poder constituinte, ao qual se devem submeter todas as instituições públicas.

Defendemos aqui que os Anais da ANC - diferentes de anais médicos ou de eventos acadêmicos - são um gênero de discurso, considerando o que nos propõem Bakhtin (2011) - conteúdo temático, estilo e construção composicional - e Maingueneau - status respectivos dos enunciadores e coenunciadores; circunstâncias temporais e locais de enunciação; suporte e os modos de difusão; temas que podem ser introduzidos; extensão e o modo de organização.

Reiteramos a pertinência da opção pela noção de gênero de discurso no que tange à discussão do córpus por nós escolhido, a partir de diálogo com Arantes e Deusdará:

\begin{abstract}
é preciso dizer que os enunciados não existem de forma isolada em uma situação de uso, o texto é a unidade da interação verbal. Por isso, os gêneros discursivos encontram-se em uma ordem superior ao valor ilocutório de enunciado, propondo certo rearranjo, ou ainda uma sobredeterminação do sentido, dependendo do gênero em que estiverem inseridos. Dessa forma, "a partir do momento em que identificou a que gênero pertence um texto, o receptor é capaz de interpretá-lo e comportar-se de modo adequado a seu respeito" (MAINGUENEAU, 1996, p. 15-16). Considerando o debate relativo aos gêneros do discurso, tal noção nos permite pensar na linguagem como força que se singulariza em situações de enunciação. Tal perspectiva contribui para pôr em xeque, de uma vez por todas, a cisão entre o linguístico e o social, já que a preocupação com os gêneros, nas reflexões de Bakhtin emerge da relação entre as "manifestações verbais" e as manifestações de natureza semiótica, mímica, gestual etc. (ARANTES; DEUSDARÁ, 2015, p. $52)$.
\end{abstract}

São 22 os volumes dos anais ${ }^{2}$ e todos possuem praticamente a mesma estrutura,

\footnotetext{
${ }^{2}$ Encontram-se digitalizados e disponíveis na biblioteca digital no portal da Câmara Legislativa Federal, http://www2.camara.leg.br
} 
em que constam nos sumários temas discutidos nas reuniões de trabalho da Assembleia, juntamente com os discursos proferidos em sessões de plenária pelos deputados constituintes. Em nossa pesquisa, a seleção do córpus foi feita da seguinte forma: buscamos nos índices dos anais a palavra imigração e verificamos que a mesma constava em todos. Selecionamos, então, os trechos de leis, emendas e pareceres, e usamos como busca o termo imigração nos documentos em PDF. A partir de então, nosso córpus passou a ser constituído pelos fragmentos dos documentos em que o termo aparecia, a saber, Anais IV, páginas 211-216, 219, 490-493, e Anais XIX, páginas 340349 e 546-549, tendo sido desprezados os outros.

Os Anais são constituídos por outros gêneros, tais como artigos, leis, emendas, pareceres e discursos proferidos em sessões, sendo os três primeiros bastante estáveis.

As discussões são apresentadas, em geral, da seguinte forma: primeiro o artigo que consta na lei anterior, um parágrafo com a alteração pretendida, em seguida, um texto em que o(s) autor(es) teceram argumentos para justificar suas propostas de mudança.

Por questões metodológicas, selecionamos como córpus da pesquisa que originou este artigo apenas os discursos que se materializaram em documentos legais projetos de leis, emendas e pareceres relacionados a questões étnico-raciais-, encontrados nos anais em questão, por entendermos que esses documentos, mesmo que não reproduzam os discursos proferidos à época, são o resultado dos embates que se materializaram discursivamente.

Neste artigo, apresentamos três fragmentos nos quais trabalhamos com categorias diversas, seguindo uma semântica global (MAINGUENEAU, 2008), que

\footnotetext{
nos ajuda a entender, que, em um texto, forma e conteúdo não estão dissociados e se relacionam em todos os planos discursivos- vocabulários, modos de enunciar, dêixis, temas- construindo significados que se materializam no texto. E cabe ao analista buscar indícios nesse texto que o remetam a determinada prática discursiva (GIORGI, 2012, p. 120).
}

Portanto, no intuito de identificar discursos racistas e os efeitos no documento em questão, recorrer a uma semântica global permite que as análises destaquem pontos diversos e que se façam relevantes ao longo de sua construção, ou seja, em lugar de 
escolhas predeterminadas e engessantes, as categorias de análise serão escolhidas pelo pesquisador à medida que se façam necessárias (GIORGI, 2012, p. 120).

Em seguida, trazemos a emenda N.1619, parte dos ANC, apresentada e aprovada em 25 de abril de 1934, que passou a regular a entrada de imigrantes em território nacional, assinada por 130 deputados e aprovada na sessão de 24 de maio de 1934, por 146 votos a favor e 41 contra.

\begin{tabular}{|c|c|c|}
\hline ento 1 & $25 / 05 / 1934$ & ANAIS, v. XIX, p. 340 \\
\hline $\begin{array}{l}\text { Depois de 1914, certas n } \\
\text { tinham em casa o problema da fa } \\
\text { revolucionário, mal tomou conta da } \\
\text { 19.942, ainda em vigor, que fecha } \\
\text { descontava mensalmente na folha d } \\
\text { distribuir pelos sem emprego em ne } \\
\text { Por outro lado, os paíse } \\
\text { homem - que é em todo mundo a pr } \\
\text { as seduções das prosperidades er } \\
\text { encaminhando o excedente dos se } \\
\text { negando passaporte para o estrange } \\
\text { 300 mil emigrantes, só lhe esteja m } \\
\text { da entrada imigratória, são nos país } \\
\text { dizem os americanos, para lhes dar } \\
\text { domestic law. } \\
\text { Só às nações de imigraç } \\
\text { localização no Território nacional } \\
\text { despejando nas outras, sem licença } \\
\text { transformando cada país, sem mercé } \\
\text { Os estadistas e pensado } \\
\text { maiores, S. Holmes: "Só recenteme } \\
\text { imigrantes tinham sido introduzido } \\
\text { da sua pátria um poso verdadeirame } \\
\text { não pelo desejo sentimental de ver a } \\
\text { por homens fortes, sadios e intelige } \\
\text { Outro, não menor Lothrop Stoddart } \\
\text { a diretriz que ela deu ao problema } \\
\text { de vista material, sendo o imigrant } \\
\text { produção de riquezas". Foi desta } \\
\text { imigrantes da Europa nos Estados U }\end{array}$ & $\begin{array}{l}\text { blema da imigra } \\
\text { ação, reconhece } \\
\text { sil o clamor do } \\
24 \text { de Outubro d } \\
\text { toda imigração, } \\
\text {, dos funcionári } \\
\text { ração, relativam } \\
\text { er nação - resolv } \\
\text { n fizeram o gr } \\
\text { para as própria } \\
\text { que a Itália, que } \\
\text {. Em qualquer c } \\
\text { nos da sua sober } \\
\text { omesticidade; - } \\
\text { hecessidades em } \\
\text { rria resolvido o } \\
\text { opulação sem tr } \\
\text { ss. } \\
\text { fia, avisaram a } \\
\text { l, de que estávan } \\
\text { ue podiam ser as } \\
\text { Imigração, não p } \\
\text { universal dos op } \\
\text { res instintos e p } \\
\text { ais condenável n } \\
\text { ezenove, colocan } \\
\text { as um creador de } \\
\text { le nasceu em } 19 \\
\end{array}$ & $\begin{array}{l}\text { bém, por circunstâncias diversas, } \\
\text { ca era tamanho que o governo } \\
\text { m } 12 \text { de Dezembro o decreto n. } \\
\text { ocedência, ao mesmo tempo que } \\
\text { a } 2 \% \text { dos seus vencimentos para } \\
\text { os após a Guerra, no seu capital } \\
\text { sete chaves e escondê-los contra } \\
\text { e o bravo General Carmona, } \\
\text { lediterrâneo e na África, e lhes } \\
\text { expedia para a América do Norte } \\
\text { volume da saída emigratória ou } \\
\text { eis e incorríveis, ou como melhor } \\
\text { mingration is puery a manther of } \\
\text { r-lhes a qualidade e dirigir a sua } \\
\text { desocupados, por quanto iriam } \\
\text { passaria a ser um condomínio, } \\
\text { erigo iminente, dizendo um dos } \\
\text { os por uma indigestão aguda. Os } \\
\text { americano, que ambiciona fazer } \\
\text { braço barato lhe possa importar, } \\
\text { lo ideal de uma América povoada } \\
\text { comporem a harmonia da vida". } \\
\text { ão esgotada e materialista do que } \\
\text { to de vista da raça, mas no ponto } \\
\text { s, mas um mero utensílio para a } \\
\text { que reduziu a } 2 \% \text { a entrada de }\end{array}$ \\
\hline
\end{tabular}

Conforme Maingueneau (2013) designação são os termos que escolhemos, dentro do leque de opções que há para designar, apresentar um referente ou seus diversos modos de apresentação. Estes permitem ao coenunciador identificar o referente com um sentido mais próximo daquele indicado pelo enunciador. No fragmento acima transcrito, observamos que esses termos nos permitem identificar um alinhamento entre o enunciador e o chefe fascista de Estado da Itália, Benito Mussolini, e com o general Óscar Carmona, presidente da República Portuguesa (1926-1951) graças a um golpe de 
Estado: “Assim fizeram o grande Mussolini e o bravo general Carmona". Alinhamento esse que nos remete ao período após a Primeira Guerra, conhecido como crise do capitalismo imperialista, em que surgiram na América Latina e também na Europa regimes que possuíam como principal característica o autoritarismo. A exaltação a Mussolini, marcada pela adjetivação grande, e ao general Carmona, por meio de bravo no documento, nos remetem a uma aproximação do governo brasileiro à fundação da Ação Integralista Brasileira (AIB), movimento político inspirado no fascismo, fundado por figuras expressivas como Plínio Salgado e Miguel Reale, participantes da Revolução Constitucionalista de 1932.

A mesma categoria nos possibilita observar que a imagem de imigrante construída no fragmento 1 não recupera a tragédia e os resultados da destruição da guerra como questão humanitária, que seria um problema para todas as nações do globo. A imigração é tratada meramente como uma busca de prosperidades em terra estranha, como se o refúgio estivesse somente atrelado a questões econômicas individuais e, em alguns casos, pudesse ser aproveitado também para fazer crescer economicamente uma nação: "os Estados Americanos, reservam o direito de examinar as vantagens em receber quaisquer correntes de imigração e agir como melhor lhes parecer na defesa dos seus interesses". Sendo assim, a questão humanitária, a defesa da vida e dos direitos dos cidadãos imigrantes são invisibilizados em detrimento da prosperidade econômica individual (imigrantes querem fazer riqueza em terras estrangeiras) ou da nação (a nação pode levar vantagens econômicas ao receber imigrantes em seu território).

Do mesmo modo, as designações contribuem para a compreensão do modo como foram construídas discursivamente as imagens e sentidos sobre os imigrantes, como verificou-se no excerto referente à proposta de lei apresentada por Antônio Xavier de Oliveira (1892-1953), natural de Juazeiro (Ceará), médico pela Faculdade de Medicina do Rio de Janeiro, que foi eleito deputado constituinte (1933) pelo Ceará, na legenda da Liga Eleitoral Católica, no dia 22 de dezembro de 1933:

\begin{tabular}{|c|c|c|}
\hline Fragmento 2 & 22/12/1932 & AANC, v. XIX, p. 546 \\
\hline $\begin{array}{l}\text { N.1164 } \\
\text { Art. Para o efeito de resid } \\
\text { dência. } \\
\text { Parágrafo único. É obrig }\end{array}$ & $\begin{array}{l}\text { da no país de el } \\
\text { lade física e me }\end{array}$ & $\begin{array}{l}\text { as negras e amarela, de qualquer } \\
\text { imigrante ou estrangeiro que se }\end{array}$ \\
\hline
\end{tabular}


destine ao território nacional ou que se queira naturalizar cidadão brasileiro.

Justificação

O problema das raças humanas, cada vez mais assume preponderância notável, entre os que em maior relevo são havidos pelas nações organizadas na hora atual da humanidade. De outro não sei o que sobrepuje em importância para a vida dos povos, maximé, para um país em formação como o Brasil, pois a meu ver, nenhum lhe corre parelhas na ordem das grandes cogitações, que ora devem ocupar as suas "elites" científicas, e todos os seus homens de cultura, profana ou religiosa, nomeadamente, os seus homens de governo. (...) O homem- até os rebutalhos de raças, mais ou menos, degeneradas, como algumas da Ásia Oriental, além de outras, quiça tão indesejáveis, como todas as do Oriente próximo (Ásia Menor), aquelas e estas, boas ou más, sãs ou doentes, inferiores ou superiores, mas, todas, para a nossa formação eugênica, só comparáveis aos insanos incuráveis de outros povos, que também recebemos e tratamos e mantemos em nossos hospitais, sempre superlotados. Esta a tese que procurei desenvolver na ementa, supra, que, entretanto envolve assunto de mágma importância para o Brasil, como igualmente para todas as demais nações do Continente Americano. (...) Não é possível continuarmos a receber africanos, asiáticos e outros indesejáveis inclusive, psicopatas, de todas as partes do mundo. Ademais, é um assunto este da seleção dos imigrantes, que, por igual, deve interessar tanto a nação que envia, como a que recebe o migrador. Este, para vencer e não naufragar no novo "habitat" que vai procurar, deve ser, tem que ser, forçosamente um forte.

Vou além um pouco, para afirmar que o duende da humanidade, como o sol, vem do Oriente para o Ocidente. E não sei bem se me afasto do tema que desenvolvo afirmando que, mentalmente o oriental nos é indesejável; nem se deixa de ser bom brasileiro jurando que o Brasil não deve ser a terra prometida de Israel, nem a Amazônia a Manchúria do futuro.

(..) Como se está a ver, a importância dessa questão está em uma simples enunciação: Jamais seremos uma grande nação se não cuidarmos de defender e melhorar a nossa raça.

Segundo Maingueneau, as designações presentes no fragmento anterior, relativas às raças negras e amarelas, são do tipo definida, que, de acordo com o autor (2013, p. 243), obrigam "o coenunciador a escolher um indivíduo, ou um conjunto de indivíduos, caracterizando-os por intermédio de uma ou várias propriedades". O contexto também faz parte desse tipo de designação. Em uma sociedade que permite a divisão das pessoas em raças, algumas superiores e outras inferiores, elementos da raça negra e amarela podem ser e são proibidos, prevalecendo apenas os da raça branca, considerada superior às demais. Os imigrantes, dependendo de sua localização de origem, são apresentados de modo negativo ou positivo. Por exemplo, se for asiático ou africano, é indesejável, como observamos no enunciado: "Não é possível continuarmos a receber africanos, asiáticos e outros indesejáveis inclusive, psicopatas, de todas as partes do mundo". O uso do termo outros confirma que aqueles citados anteriormente eram indesejáveis, e, além disso, coloca no mesmo plano africanos, asiáticos e psicopatas de origens distintas.

Essas restrições estabelecidas ao longo do fragmento (obrigatoriedade de exame de sanidade física e mental, indesejabilidade de povos de origem asiática e africana) dialogam com vozes não-ditas no fragmento, mas que podem ser recuperadas: são as vozes dos discursos da medicina, da psicologia e da antropologia da época, que se baseavam em critérios quantitativos (medições de crânio, presença de células, cor de pele, etc) para determinar a existência de raças inferiores e raças superiores.

Mais uma vez, o discurso da aceitabilidade de determinados imigrantes em 
território nacional é pautado em questões econômicas e não humanitárias: "Como se está a ver, a importância dessa questão está em uma simples enunciação: Jamais seremos uma grande nação se não cuidarmos de defender e melhorar a nossa raça". O problema do refúgio e as consequências da guerra para a humanidade são invisibilizadas, tornando os imigrantes apenas instrumentos de mão de obra, meros objetos descartáveis, necessários somente para a prosperidade econômica da nação.

A uma perspectiva discursiva interessam, fundamentalmente, os efeitos de sentidos produzidos pela negação polêmica: "a possibilidade de identificar duas vozes distintas encenando um embate de posicionamentos em relação a um dado tema, uma polarização de pontos de vista" (RODRIGUES; ALMEIDA, 2007, p. 75). A rejeição de um determinado ponto de vista ocorre de forma concomitante com a presença do enunciador que nega algo, pondo imediatamente o foco sobre um enunciador que afirma esse algo e marca a presença de um outro no discurso, o que nos remete à discussão sobre heterogeneidade discursiva.

A polêmica não se instaura entre dois sujeitos individualmente, mas entre duas posições de sujeitos que representam "formações discursivas antagônicas".

Segue fragmento da emenda constitucional, N. 1053, apresentada no dia 19 de dezembro de 1934 pelo deputado constituinte Arthur Neiva, do PSD (Partido Social Democrático) da Bahia, e demais deputados constituintes da bancada baiana.

\begin{tabular}{|c|c|c|}
\hline Fragmento 3 & 19/12/1933 & AANC IV, p. 211 \\
\hline $\begin{array}{r}\text { Art. 128, 2\$- } \\
\text { massa, em qualquer pont } \\
\text { Ninguém supo } \\
\text { (...) A solução } \\
\text { (..) O Brasil c } \\
\text { um século, estará inteiran } \\
\text { que tem chamado a ate } \\
\text { alimentar correntes imig } \\
\text { outras línguas e princípio } \\
\text { Art. 128 } 3 \text {. } \\
\text { A comissão que } \\
\text { limitar ou favorecer a emigra } \\
\text { país deve ser regulada no } \\
\text { psicológicas, de modo que a } \\
\text { das massas demográficas de } \\
\text { Como se vê, o p } \\
\text { nação como a nossa, com im }\end{array}$ & $\begin{array}{l}\text { nentos da raça br } \\
\text { stificação } \\
\text { em de longe, qua } \\
\text { aças, foi a mais i } \\
\text { e um povo onde } n \\
\text { oosevelt e Kays } \\
\text { siáticos ou de pre } \\
\text { escreveu no art. } \\
\text { esses nacionais. } S \\
\text { ientadas pelas co } \\
\text { lano se faça por q } \\
\text { sua assimilação a } \\
\text { cação } \\
\text { omplexidade, sen } \\
\text { ndo convenientem }\end{array}$ & $\begin{array}{l}\text { do proibida a concentração em } \\
\text { ceito de raça. } \\
\text { ossível, em um prazo menor de } \\
\text { reconceitos de raça e religião, o } \\
\text { outros. E não seria oportuno } \\
\text { os e americanos, portadores de } \\
\text { lei federal poderá proibir, } \\
\text { A entrada de imigrantes no } \\
\text { s etnológicas, higiênicas e } \\
\text { s, de acordo com o volume } \\
\text { acional. } \\
\text { mais importantes para uma } \\
\text { eprojeto. Além dos aspectos }\end{array}$ \\
\hline
\end{tabular}


médicos propriamente ditos (etnológicos, higiênicos, profilático, etc.) apresentam as correntes imigratórias as componentes dinâmicas da formação nacional, que oscila como uma boa ou má triagem do material humano, no preenchimento dos seus vastos demográficos como, na sua composição do normatipo nacional.

No enunciado “o Brasil dá o exemplo único em todo o mundo de um povo onde não existem preconceitos de raça e religião", identificamos a marca da negação polêmica conceituada por Ducrot (1987). A necessidade de se negar a existência do preconceito, quer do signatário da emenda, quer do país, aponta para um discurso que afirma existirem no Brasil preconceitos de raça e religião, conforme denunciava a imprensa Negra Paulista, formada por periódicos ligados aos movimentos negros em São Paulo, que eram organizados em torno das associações dos homens de cor, nas primeiras décadas do século XX. Evidenciavam-se as práticas racistas sofridas pela população negra recém-liberta, como podemos verificar no fragmento abaixo retirado do periódico $O$ Alfinete, escrito em agosto de 1918:

\footnotetext{
O estado lamentável em que jazem os homens de cor no Brasil, oprimidos de um lado pelas ideias escravocratas em que de todo não despareceram do nosso meio social, e de outro, pela nefasta ignorância em que vegetam este elemento da raça brasileira, inconsciente da sua humildade(...) a ignorância e a fraternidade dos povos preconizadas pelos princípios de 89 na França e que a República implantou como símbolo de nossa democracia, com relação aos negros é uma ficção, é uma mentira que até hoje não foram postas em prática (...) a raça branca opulenta, como é, exercendo o seu poderio revoltante compele a preta a viver em eterna inferioridade (OLVEIRA, 1918 apud PIRES, 2005, p. 75).
}

A denúncia do racismo era realizada através da imprensa, mas o discurso hegemônico no campo político está evidentemente atravessado pela obra de Gilberto Freyre, que contribuiu para a formação do mito da democracia racial brasileira, em que as oportunidades são iguais para todos independente das raças, tornando-se presente na justificativa do projeto de lei, ao negar a existência do racismo.

A imigração, como procuramos mostrar neste trabalho, além de colaborar para a ocupação do território, tinha como objetivo contribuir para a formação da identidade nacional brasileira e, sobretudo, para a prosperidade econômica, servindo às classes dirigentes, que, influenciadas pelas teorias racialistas, desejavam um país branco, aos moldes da Europa. 
É nítida a presença do discurso eugenista no enunciado: "A entrada de imigrantes deve ser regulada no sentido dos interesses nacionais e orientadas pelas conveniências etnológicas, higiênicas e psicológicas, dado que a eugenia possuía diversas linhas de front em prol do melhoramento da raça: a) controlar a entrada dos imigrantes de acordo com a sua localização (questões etnológicas), b) restringir a entrada de degenerados como alcóolatras, tarados e pessoas envolvidas com crimes, e c) a questão higiênica, pois os imigrantes deveriam ser saudáveis, de modo a contribuir ao melhoramento racial. Essas exigências dialogam com vozes não-ditas e implícitos que nos levam a considerar a questão da imigração no pós-guerra como centralmente articulada com a prosperidade econômica das nações que receberiam esses imigrantes, vistos como instrumentos, objetos de mão de obra.

\section{Considerações finais}

A pesquisa se propôs, a partir da análise de implícitos e de categorias da linguística enunciativa e da análise do discurso, compreender as relações de sentido que foram criadas em torno da imigração nas reuniões de trabalho de ANC 1933-34, e as relações entre esse conceito de imigração com os sentidos estabelecidos para raça e eugenia.

Identificamos que essas relações dialógicas criam sentidos sobre imigração, sem mesmo se propor, centralmente, a fazer esse debate, pois analisar o que não está dito nos enunciados nos proporciona ver que um discurso não se constitui de um só enunciado, pois se assim pensássemos, suporíamos que "o sujeito falante o teria apresentado como objeto de uma única escolha" (DUCROT, 1987, p. 164), o que não acreditamos ser verdade, pois "o que o sujeito falante comunica através de seu enunciado é uma qualificação da enunciação deste enunciado" (DUCROT, 1987, p. 172).

A negação de racismo por parte do Estado brasileiro, através do órgão legislativo, nos pareceu uma falácia, pois, como demonstramos, numa configuração onde seres humanos são classificados enquanto raças, algumas superiores e outras 
inferiores, alguns projetos de leis foram apresentados no intuito de restringir e ou proibir a entrada daqueles considerados racialmente inferiores, tais como negros e asiáticos. O branqueamento continuou a vigorar enquanto política pública de Estado, onde identificamos a preferência para a imigração de estrangeiros brancos, sobretudo do norte da Europa, considerado as raças mais superiores de acordo com o discurso científico da época. Sendo assim, percebeu-se, através da categoria de negação polêmica, que, ao negar a existência de racismo, ativa-se a existência do racismo, pois não podemos negar o que não existe, somente o que existe.

A discussão a respeito da identidade nacional, iniciada nas primeiras décadas da história republicana, continua em pauta na década de 1930, materializada discursivamente na legislação referente à entrada de estrangeiros em território nacional. Uma escolha que não se deu por acaso, pois coube ao saber eugênico, influenciado pelas teorias racialistas, selecionar ou restringir a entrada de imigrantes, o que pode ser visto no projeto de lei apresentado por Xavier de Oliveira, em que o deputado julgava necessária uma avaliação da sanidade mental dos imigrantes, de modo a restringir a entrada daqueles considerados degenerados: alcoólatras, psicopatas, tarados e criminosos. A raça branca, considerada superior, era detentora de privilégios, ao passo que as raças negra e amarela eram consideradas inferiores.

\section{REFERÊNCIAS}

ALMEIDA, F. S.; RODRIGUES, I. C. Enunciação e heterogeneidade: o que (não) é um Role Playing Game?. In: Vera Sant'anna; Bruno Deusdará. (Org.). Trajetórias em Enunciação e Discurso: Conceitos e Práticas. Claraluz, 2007, p. 71-81.

ARANTES, P.; DEUSDARÁ, B. Português para refugiados: aliando pragmática e discurso em resposta a uma demanda concreta. Letrônica, Porto Alegre, v. 8, n. 1, p. 4559, jan.-jun. 2015.

BAKHTIN, M. Marxismo e Filosofia da Linguagem. São Paulo: HUCITEC, 2003. . Estética da Criação Verbal. São Paulo: Martins Fontes, 2011.

BANTON, M. A ideia de raça. Lisboa: Editora 70, 1977.

COSTA, S. A mestiçagem e seus contrários - etnicidade e nacionalidade no Brasil 
contemporâneo. In: Tempo Social, USP, São Paulo, 2001.

DUCROT, O. O Dizer e o Dito. São Paulo: Pontes, 1987.

FOUCAULT, M. Microfísica do Poder. São Paulo: Edições Graal, 2007.

. A Arqueologia do Saber. Rio de Janeiro: Forense Universitária, 2009.

GIORGI, M. C. Da Escola Técnica à Universidade Tecnológica: o lugar da educação de nível médio no Plano de Desenvolvimento Institucional do CEFET/RJ. Tese (Doutorado em Linguística) - Instituto de Letras, Universidade Federal Fluminense, Rio de Janeiro, 2012.

; BIAR, L.; BORGES, R. C. Estudos da linguagem e questões étnico-raciais: contribuições e limites. In Revista da ABPN, v. 7 n. 17, 2015.

GRAHAM, R. Construindo uma nação no Brasil do século XIX: visões novas e antigas sobre classe, cultura e Estado, v. 5, n. 1, p. 11-47, 2001

MAINGUENEAU, Dominique. Análise de Textos de Comunicação. São Paulo: Cortez Editora, 2013.

Gênese dos discursos. Curitiba: Criar Edições, 2005.

Discutir Texto, Gênero e discurso. São Paulo: Parábola Editorial, 2008.

Novas tendências em Análise do Discurso. Campinas: Pontes, 1997.

MUNANGA, K. Rediscutindo a Mestiçagem no Brasil: identidade nacional versus identidade negra. Belo Horizonte: Autêntica, 2004.

PIRES, A. Associações de Homens de Cor - ideologias sociais (1915-1935). In: SALGUEIRO, M.A.A. República e a Questão do Negro no Brasil. Rio de Janeiro: Editora Museu da República, 2005.

ROCHA, D. Representar e intervir: linguagem, prática discursiva e performatividade. Linguagem em (Dis) curso - LemD, Tubarão, SC, v. 14, n. 3, 2014, p. 619-632.

Representação e intervenção: produção de subjetividade na linguagem.

Gragoatá. Niterói: Ed. UFF, v. 21, 2006, p. 355-372, .

SKIDMORE, T. E. Preto no branco: raça e nacionalidade no pensamento brasileiro (1870-1930). São Paulo: Companhia das Letras, 2012.

STEPAN, N. A Hora da Eugenia: raça, gênero e nação na América Latina. Rio de Janeiro: Editora Fiocruz, 2005. 
TRINDADE, H. Integralismo: o Fascismo Brasileiro na Década de 30. São Paulo: Difusão Européia do Livro, 1974. 